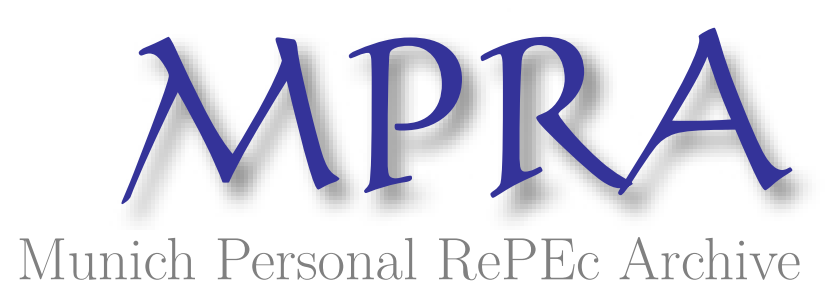

\title{
Bank loan loss provisions, risk-taking and bank intangibles
}

Ozili, Peterson K

Central Bank of Nigeria

1 January 2019

Online at https://mpra.ub.uni-muenchen.de/90273/

MPRA Paper No. 90273, posted 30 Nov 2018 07:14 UTC 


\title{
Bank Loan Loss Provisions, Risk-taking and Bank Intangibles
}

\section{Peterson K Ozili}

\author{
1. Monarch Business School, Monarch University, Switzerland \\ 2. University of Essex, United Kingdom. \\ 3. Central Bank of Nigeria
}




\begin{abstract}
This article investigates the relationship between discretionary loan loss provisions and bank intangibles among African banks. Prior studies examine how intangible assets affect firms' profitability and valuation decisions with almost no focus on the role of loan loss provisions. We investigate whether banks increase (decrease) loan loss provisions in response to risks associated with investment in intangible assets. We find that discretionary loan loss provisions are inversely associated with bank intangible assets and change in intangible assets, but the inverse association is weakened in environments with strong investor protection. We also observe that income smoothing is reduced among banks that have large intangible asset investment, while income smoothing is pronounced among banks that have few intangible asset investments, but this behaviour is reduced for banks in environments with strong minority shareholders' right protection.
\end{abstract}

Keywords: Banks, Income smoothing, Financial Institutions, Financial reporting, Intangible assets, Loan loss provisions, Signalling, Bank Valuation, Bank Risk-taking, Africa.

JEL Codes : G21, G32, M41 


\section{Introduction}

This article investigates the relationship between discretionary loan loss provisions and bank intangibles among African banks. Intangible assets have been rising on bank balance sheets and are growing in importance. Intangible assets pose unique challenges to auditors in terms of complexity and judgment (Visvanathan, 2017), and pose some challenge to banks in terms of measurement and valuation and pose a challenge to standard setters in terms of classification of unidentifiable intangible assets.

Investment in intangible assets pose some risks to banks, and banks will adopt several techniques to mitigate the risks emanating from intangible assets investment. Among the set of techniques that banks can adopt, banks can use discretionary accounting numbers to reduce intangible asset investment risk. Surprisingly, there is little knowledge in the literature about specific accounting techniques (or numbers) that banks employ to mitigate intangible asset investment risk; hence, this is worth investigating given the important role of financial reporting for banks' risk management and firm stability objectives. This study is the first attempt in the literature to link bank loan loss provisions with bank intangibles while controlling for institutional differences (investor protection) across countries.

Bank loan loss provision is an amount set aside by banks to mitigate expected losses on bank loan portfolio. Studies show that banks can use discretionary loan loss provisions to smooth income, to manage capital levels or to signal information about firm's earnings prospects (see, Scholes et al, 1990; Kanagaretnam et al, 2005; Leventis et al, 2012; Curcio and Hasan, 2015; Ozili, 2018, etc.), implying that reported loan loss provisions estimate is not solely driven by credit risk considerations but by other considerations (see, Ozili and 
Outa, 2017). We extend this observation in the literature to the case of intangible assets to detect whether the level of discretionary provisions is also influenced by intangible asset investment risks.

An intangible asset is 'an identifiable non-monetary asset without physical substance' (IASB, 2004: p.2), or 'a non-current, non-financial claim to future benefits that lacks a physical or financial term' (FASB, 2001; p.6). Bank intangible assets are non-physical assets including human capital, intellectual capital, social capital (or business relationships), ideas and knowledge about the banking, economic and business environment that generate value and income to banks to improve bank equity valuation both in primitive and modern economies.

From a system perspective, bank intangibles are a subset of economic intangibles which in turn are a subset of cultural intangibles and are cumulative, synergistic, and frequently inseparable from other tangible assets and are not owned by any single bank or firm (Basu and Waymire, 2008). For this reason, we take a holistic approach to bank intangibles rather than separating them into individual components, and we also focus on the accounting value of total intangibles rather than a separate accounting value for individual intangible assets of banks. By intangible asset investment, we mean the total value of intangible assets reported in bank balance sheet.

Investment in intangible assets are crucial for banks, and such investment in intangible assets provide benefits and risks to banks (Chen et al, 2014; Donaldson, 2016). One risk that intangible assets pose to banks is the risk that investment in intangible assets will not yield its anticipated gains in the future. Bank managers are concerned about this risk, and their 
concern is further amplified when bank shareholders and potential investors are sceptical about investment in intangible assets particularly when shareholders view intangible assets as mere propositions that are subject to technological risk, reputation risk and related uncertainties. In response to these risk concerns, we argue that bank managers may keep additional or fewer loan loss provisions in response to unexpected (or abnormal) changes in intangible asset investment, and this behaviour can have significant signalling effect to shareholders.

We obtain bank data for intangibles and loan loss provisions for several African countries from Bankscope database for the 2002 to 2014 period. We find that discretionary loan loss provisions are inversely associated with intangible assets and change in intangible assets, but the association is weakened in strong investor protection environments. Income smoothing is reduced when African banks that have large intangible asset investments. We find that income smoothing is more pronounced among African banks that have few intangible asset investments but this behavior is reduced among banks in strong investor protection environments.

This study makes three contributions to the literature. One, we contribute to the literature that examine the role of accounting numbers for effective risk management (e.g., Bushman and Williams, 2012; Cohen et al, 2014; Riro et al, 2016). By focussing on intangible asset investment risk, we provide some insights to understand how the level of bank provisions may be driven by the need to set-aside additional provisions 'buffer' to mitigate or manage the risks emanating from investment in intangible assets. It is important to understand 
whether bank managers use their provisioning discretion to influence loan loss provisions estimate in response to changes in investment in intangible assets.

Two, we contribute to the literature that investigate the influence of institutional factors on bank financial reporting behaviour (e.g., Amor, 2017; Ozili, 2018; Curcio and Hasan, 2015; Fonseca and Gonzalez, 2008). By controlling for investor protection differences, we provide insights to understand how the level of investor protection can influence the association between loan loss provisions and bank intangibles. Three, we examine banks in a region that do not have standardised reporting for bank intangibles - the African region, and this allows us to ensure that the reported values for bank intangibles reflect (and incorporate) significant managerial discretion, so that we can gain some insights on whether managerial discretion in provisioning is influenced by the risk associated with intangible asset investment.

The remainder of the study is organised as follows. Section 2 presents the conceptual framework and the literature review. We discuss the accounting disclosure for intangibles and bank intangibles. We also review the literature on discretionary provisions and intangibles. Section 3 develops the hypothesis. Section 4 presents the data and methodology. Section 5 presents and discuss the empirical results. Section 6 concludes. 


\section{Conceptual Framework and Literature Review}

\subsection{Intangibles: Disclosure Rules and Evidence}

Under IFRS and FASB accounting frameworks, intangible investments should be expensed or capitalised when incurred, and should be the case if all intangible investments are classified as intangible assets; but in reality, not all intangible investments of firms are considered as intangible assets (Lev, 2001). According to the IASB, intangible investments are considered as 'intangible assets' in the balance sheet of firms if intangible investments represent 'an identifiable non-monetary asset without physical substance' (IASB, 2004: p.2), or if intangible investments represent 'a non-current, non-financial claim to future benefits that lacks a physical or financial term' (FASB, 2001; p.6). Lev (2001) points out the weakness of these two accounting frameworks for intangibles.

Lev (2001) use the case of employee skill and knowledge as an example and points out that although firms invest in employee training, firms do not own the employees or the ideas in the head of employees. Employees can switch employers as quickly as possible; hence this kind of intangible investment cannot be capitalised or expensed based on the current accounting framework. Clearly, Lev (2001) demonstrates that the current accounting framework has issues related with the recognition of intangible investments. According to IASB IAS 38 and FASB SFAC5, the recognition criterion for intangible investment is the 'reliability of measurement of asset cost'. This recognition criterion is also criticised because it is difficult to reliably measure internally-generated assets such as software, trademarks, patents etc. Also, the lack of recognition of some intangible investments as "intangible assets" is mainly due to issues related to the identification, measurement, and control of intangibles (Zéghal and Maaloul, 2011); and has consequences 
for the value-relevance of financial information (Lev and Zarowin, 1999; Brown et al, 1999), resource allocation in equity markets (Seow et al, 2006), and firm market value (Eberhart et al, 2004; Garcia-Ayuso, 2003).

Regarding disclosures, firms may voluntarily disclose information about intangibles to lower the consequences of the recognition issues associated with intangible investments. Jones (2007) observe that managers of intangibles-intensive firms voluntarily disclose additional information on intangible investments in financial reports and conference calls to explain firm market value when financial information is perceived to be less value-relevant. Kristandl and Bontis (2007) observe that firms engage in, and increase forward-looking disclosures on intangibles to lower the cost of capital. Orens et al (2009) find similar result, while Vergauwen et al (2007) show that firms disclose additional information on intangibles when they have higher intangible assets. Abdolmohammadi (2005) show that increased disclosure of intangibles information in financial reports is followed by increase in market capitalization in high-technology US firms.

Oliveira et al (2010), in a study of firms in the Portuguese stock exchange, find that the change to IAS/IFRS had no impact on the value relevance of total intangible assets as a whole, but find evidence for increased value relevance when the subclasses of identifiable intangible assets are considered. Visvanathan (2017) argue that, in contrast to tangible assets, intangible assets pose unique challenges to auditors in terms judgment and complexity, and find that auditors charge higher fees for firms with higher proportion of intangible assets on the balance sheet. Regarding firm performance, Andonova and RuízPava (2016) investigate the performance of Colombian firms and find that intangible assets 
are drivers of firm performance, implying that intangible assets give firms a competitive advantage in an emerging environment. However, the propensity to invest in intangibles may depend on the characteristic of the firm. Arrighetti et al (2014) show that firms with higher human capital, larger size, and a large intangible asset base have greater propensity to invest in intangible assets.

\subsection{Bank Intangibles and Risk}

As we stated earlier, bank intangibles consist of human capital, core depositor relationships, mortgage and other loan servicing relationships, credit card customer relationships, leasing customer relationships, brand names, computer software and technologies (including bank account management software and financing accounting software) and the associated databases that operate on bank's software (Reily, 2010), and these intangible assets generate value and income to improve bank equity valuation both in primitive and modern economies (Basu and Waymire, 2008).

The valuation of bank intangibles is important for financial reporting purposes, intangible asset sale and ownership transfer purposes, tax planning and compliance purposes, infringement and litigation claims purposes, commercial dispute resolution purposes, corporate management information purposes, corporate governance and contractual compliance purposes, bankruptcy and firm restructuring purposes. Also, the valuation of bank intangible assets involves the experience and expertise of economists, academics, industry consultants, licensing executives, business appraisers that provide some combination of financial analysis, empirical research, due diligence, and practical experience and skills to generate a fair value for bank intangible assets. 
Regarding disclosure, banks may have weak incentive to use greater disclosures on intangibles to lower their cost of capital or to improve the value relevance of financial information simply because banks are not intangibles-intensive firms compared to technological firms. However, bank managers that have concerns about whether investment in intangible assets will yield its anticipated benefits may set aside some 'safety net' or 'provisions' to mitigate this risk. Alternatively, if it becomes apparent that investment in intangible assets will not yield its anticipated benefits, bank managers can find ways to signal this information to investors or outsiders ${ }^{1}$, and this is intuitive because managers use accounting numbers to signal private information to bank owners or outsiders to reduce the adverse selection problem arising from information asymmetry. Taken together, we argue that banks can use loan loss provisions to signal information about intangibles, or may use loan loss provisions as a safety net to mitigate the risks arising from investment in intangible assets.

\subsection{Loan Loss Provisions: Evidence}

Some studies show that banks use loan loss provisions estimate as a tool to signal information about banks' future prospect (Ozili and Outa, 2017). For instance, Beaver et al (1989) investigate US banks and find that loan loss provisions are correlated with bank market values indicating that loan loss provisions are used to signal bank's financial strength. Beaver and Engel (1996) also observe a positive effect of discretionary loan loss provisions on stock price for US banks indicating signalling via loan loss provisions. Wahlen (1994) find that US banks increase discretionary loan loss provisions to signal positive

\footnotetext{
${ }^{1}$ This supports the view of Akerlof (1970) who demonstrate that firms will signal information to firm owners to reduce adverse selection problems arising from asymmetric information between managers and firm owners.
} 
information about future cash flow to investors. Liu et al (1997) observe a positive market reaction to unexpected increase in loan loss provisions among banks with low regulatory capital levels and only in the fourth fiscal quarter. Kanagaretnam et al (2005) observe that US banks use loan loss provisions to signal information about banks prospects but the propensity to use provisions for signalling purposes is greater among smaller banks. Leventis et al (2012) investigate whether EU listed commercial banks use loan loss provisions to signal information about banks' future prospect after IFRS adoption, and find that financially distressed banks use loan loss provisions to signal firm's future prospect. On the other hand, Kanagaretnam et al (2004) investigate US banks, and find that banks use loan loss provisions to smooth income but not to signal private information about bank's future. Ozili (2015) find weak evidence for signalling via loan loss provisions among Nigerian banks. Curcio and Hasan (2015) find that non-Euro Area credit institutions use loan loss provisions for income smoothing purposes more than for capital management and signalling purposes. Morris et al (2016) investigate the economic determinants and value relevance of US banks' loan loss provisions during the global financial crisis. They find that discretionary provisions are used for smoothing and signalling when the two incentives reinforce each other, but smoothing occurs more frequently. Overall, evidence for signalling via loan loss provisions is mixed in the literature.

Regarding investor protection, Ozili (2018) investigate the non-discretionary determinants of bank loan loss provisions in Africa and find that non-performing loans, loan-to-asset ratio and loan growth are significant non-discretionary drivers of bank provisions. They also observe that (i) the increase in bank lending leads to fewer bank provisions in African countries with strong investor protection, and (ii) the propensity to use loan loss provisions 
to smooth income is reduced in environments with strong investor protection. Fonseca and Gonzalez (2008) show that the use of loan loss provisions to smooth bank earnings is significantly reduced when banks are in environments with strong investor protection. Shen and Chih (2005) document similar findings. The findings of Fonseca and Gonzalez (2008), Shen and Chih (2005) and Ozili (2018) imply that the presence of strong institutions might discourage managerial opportunistic behaviour that take the form of income smoothing via loan loss provisions among banks. Currently, there is scant knowledge on the impact of investor protection on the provisioning practices of banks in Africa.

\section{Hypotheses development}

Nicolo and Pelizzon (2008) show that banks with superior abilities hedge credit risk through derivative contracts to reduce adverse selection problems arising from information asymmetry. Banks with superior abilities can signal to investors their ability to reduce credit risk on bank loan portfolio. Liu and Ryan (1995) and Wahlen (1994) show that banks use additional loan loss provisions estimates to signal good news or bad news about banks' future prospect and other bank characteristics after controlling for non-discretionary determinant of provisions. Liu et al (1997) observe that higher loan loss provisions are perceived as good news only for risky banks while Liu and Ryan (1995) show that high loan loss provisions are perceived as good news for banks with loan default risk problems. Following the reasoning above, we maintain that loan loss provisions can be a signalling tool and we postulate that banks use loan loss provisions to signal good or bad news about the riskiness of banks' intangible asset portfolio as a whole. 
To develop the hypothesis, we propose that banks, that have insufficient resources and weak control systems to ensure that intangible asset investments yield their expected benefits, will keep higher discretionary provisions when they increase their investment in intangible assets to signal the risk associated with investment in intangible assets. When this is the case, a positive relationship between bank provisions and bank intangible assets is expected.

H1: A positive relationship between bank intangibles and loan loss provisions is expected.

On the other hand, banks that have sufficient resources and better control systems to ensure that investment in intangible assets yield their expected benefits, will keep fewer discretionary provisions when they increase their investment in intangible assets. When this is the case, a negative relationship between bank provisions and bank intangible assets is expected.

$\mathrm{H} 2$ : A negative relationship between bank intangibles and loan loss provisions is expected.

\section{Data and Method}

\subsection{Data}

Bank income statement and balance sheet information for African banks is obtained from Bankscope database (in USD). The sample period is from 2002 to 2014 and is sufficient to cover a full economic cycle. We restrict the analysis to 19 African countries that have institutional data for investor protection and macroeconomic data for gross domestic product. The countries include: Togo, South Africa, Kenya, Ghana, Egypt, Morocco, Algeria, Senegal, Tanzania, Namibia, Zambia, Nigeria, Tunisia, Angola, Uganda, Mauritius, Botswana, 
Malawi and Mozambique. Data for real gross domestic product growth rate is collected from World Economic Forum archived in World Bank database while investor protection data is collected from Doing Business Project database. See Appendix for source of data and variable description.

Banks that have missing or insufficient loan loss provisions data for four consecutive years in Bankscope database were excluded from the sample, and the resulting bank sample is 370 banks. Of the 370 banks, we further exclude banks with missing or insufficient data for intangible asset for up to four consecutive years, and the resulting final sample is 282 banks. To clean the data distribution, we eliminate outliers in the observations at the top and bottom at $99 \%$ and $1 \%$, respectively and the final sample yields an unbalanced panel consisting of 282 banks from 19 countries.

\subsection{Methodology}

The model specification to test for the association between loan loss provisions and bank intangibles is given below.

$$
\begin{array}{rr}
\text { LLPi, } \mathrm{j}, \mathrm{t}=\beta 1 \mathrm{TNi}, \mathrm{j}, \mathrm{t}+\beta 2 \mathrm{LOANi}, \mathrm{j}, \mathrm{t}+\beta 3 \mathrm{LOTAi}, \mathrm{j}, \mathrm{t}+\beta 4 \mathrm{CAPi}, \mathrm{j}, \mathrm{t}+\beta 5 \Delta \mathrm{GDPj}, \mathrm{t} \\
+\mathrm{ei}, \mathrm{t} & \text { Equation (1) }
\end{array}
$$

The model in Equation 1 is the static model and we use a dynamic model as a robustness test to capture adjustments to bank provisioning that extend beyond a one-year period and this adjustment is done by incorporating the lagged dependent variable as an explanatory variable into the main model as shown in Equation 2 below:

$$
\begin{aligned}
& \text { LLPi, j, t }=\beta 1 L L P i, j, t-1+\beta 2 T N i, j, t+\beta 3 L O A N i, j, t+\beta 4 L O T A i, j, t+\beta 5 C A P i, j, t \\
& +\beta 6 \Delta \mathrm{GDPj}, \mathrm{t}+\mathrm{ei}, \mathrm{t} \\
& \text { Equation (2) }
\end{aligned}
$$


LLP $=$ loan loss provisions to total asset ratio for bank $i$ at year $t$ and in country $j . T N=$ the ratio of intangible asset to total asset for bank $i$ at year $t$ and in country j. See Appendix for variable description.

Recall, that we predict a positive sign for TN coefficient if banks with high intangible assets investments increase discretionary provisions when they have insufficient resources and weak control systems to ensure that investment in intangible assets yield their expected benefits while we predict a negative sign for TN coefficient if banks with high investment in intangible assets decrease discretionary provisions when they have sufficient resources and strong control systems to ensure that investment in intangible assets yield their expected benefits.

Prior studies control for the non-discretionary determinants of loan loss provisions (e.g. Ahmed et al, 1999; Ozili and Outa, 2017). Loan growth (LOAN) controls for bank provisioning in response to credit risk arising from changes in bank lending (Laeven and Majnoni, 2003; Bikker and Metzemakers, 2005). Banks will keep higher provisions when they increase loan supply in environments with high credit risk vice versa; hence, a positive sign is predicted for LOAN coefficient. The second variable is net loan to total asset ratio (LOTA). LOTA controls for default risk on banks' overall loan portfolio (Fonseca and Gonzalez, 2008). Banks with higher loan to asset ratio face higher risk of loan default than banks with lower loan to asset ratio; hence, banks with higher loan to asset ratio will keep higher provisions, implying a positive sign for LOTA coefficient. CAP controls for capital management incentive to influence provisions estimates. Banks with low capital levels tend keep higher provisions to compensate for their low capital levels and vice versa (Bonin and Kosak, 2013); hence, a 
negative relationship is predicted for CAP coefficient. Real gross domestic product growth rate $(\triangle \mathrm{GDP})$ control for bank provisioning behaviour that depends on the state of the economic cycle. Bank provisions are generally higher during recessionary periods and relatively lower during economic upturns (Laeven and Majnoni, 2003); implying a negative relationship between $\triangle$ GDP and LLP. Finally, the static model is estimated with fixed effect OLS regression and the dynamic model is estimated using Generalized-Method-of-Moments $(G M M)^{2}$ first difference regression.

\section{Results}

\subsection{Descriptive Statistics and Correlation}

Table 1 is a summary of the descriptive statistics for the full sample for the 2002 to 2014 period. The mean ratio of LLP is $1.1 \%$, and indicates that bank provisions are a small fraction of banks total asset. The mean ratio of TN is $0.8 \%$ indicating that the bank intangible assets are a small proportion of bank total assets. On average, CAP is $16.10 \%$ while loan to asset ratio (LOTA) is about $50 \%$ indicating substantial reliance on loan source of funding. On average, LOAN is $20.60 \%$ indicating low growth in loans while $\triangle$ GDP ratio is about $5.6 \%$ indicating average economic growth. The correlation results in Table 2 show that TN and $\Delta \mathrm{TN}$ are positively correlated with LLP indicating that increase in intangible assets is followed by increase bank provisions. The correlation coefficients for other bank-level variables are sufficiently low to be concerned about multicollinearity in the analysis.

\footnotetext{
${ }^{2}$ Laeven and Majnoni (2003) and Fonseca and Gonzalez (2008) also use latter approach. The Arellano and Bond (1991) GMM first-difference estimator allow us to control for the autoregressive nature of bank provisioning and the likely endogeneity of the explanatory variables. We also report the GMM Sarjan (J) test for the adequacy of instruments in the GMM estimation. We also report the AR (1) and AR (2) GMM test for first-order and second-order serial correlation.
} 


\subsection{Regression Results}

The results are reported in Table 3 and 4. TN coefficient reports a negative sign and is significant at $1 \%$ level in Column 1 of Table 3 and 4 . This result confirms the second hypothesis, and implies that banks with high investment in intangible assets keep fewer discretionary provisions to signal low risk associated with intangible asset investments when they have sufficient resources and better control systems to ensure that investment in intangible assets yield their expected benefits.

For the control variables, LOTA coefficient reports the expected sign in Table 3 and 4, and implies that banks keep higher provision when they have higher loan default risk. CAP coefficient reports the expected negative sign in Table 3 and 4, and implies that banks keep higher loan loss provisions when they have lower equity capital and vice versa. LOAN and $\triangle$ GDP coefficients report conflicting signs in Table 3 and 4. Dynamic provisions (LLPt-1) coefficient is negatively significant in Table 4, indicating that high provisions in the current period are followed by fewer provisions in the next period and vice versa.

\subsection{Further Tests}

\subsubsection{Change in Intangible Assets}

Next, we test whether bank loan loss provisions are significantly associated with changes in intangible asset values after controlling for other determinants of loan loss provisions. We replace the intangible asset ratio variable (TN) with the change in intangible asset to total asset ratio $(\triangle T N)$ and the new model is shown in equation 3.

$$
\begin{array}{rr}
L L P i, j, t=\beta 1 \Delta T N i, j, t+\beta 2 L O A N i, j, t & +\beta 3 L O T A i, j, t+\beta 4 C A P i, j, t+\beta 5 \Delta G D P j, t \\
+ \text { ei, } t & \text { Equation (3) }
\end{array}
$$


The result is report in Table 3 and 4. $\Delta$ TN coefficient reports a negative sign in Column 2 of Table 3 and 4 and is significant in Table 4, indicating that loan loss provisions is inversely associated with changes in intangible assets. This result confirms the second hypothesis.

\subsubsection{Earnings smoothing and transient intangibles}

Next, we test whether the propensity to use loan loss provisions to smooth bank earnings is influenced by transient changes in the level of bank intangible assets. To do this, we first incorporate the earnings before tax and provisions variable into the model which is the earnings smoothing variable. To capture transient changes in bank intangible assets, we introduce two dummy variables, TNH and TNL, to represent periods when banks have high and low intangibles assets, respectively. The TNH dummy variable equals one if the intangible asset to total asset ratio (TN) ratio is above $1 \%$ of total bank assets and zero otherwise, representing periods when African banks have high or substantial intangibles while the TNL dummy variable equals one if intangible asset to total asset ratio (TN) ratio is less than $0.5 \%$ of bank total assets and zero otherwise, representing periods when African banks have low intangibles. We then interact TNH and THL dummies with the EBTP coefficient. The modified equation is shown below:

$$
\begin{gathered}
L L P=\beta 1 L L P t-1+\beta 2 T N+\beta 3 L O A N+\beta 4 L O T A+\beta 5 C A P+\beta 6 \triangle G D P \\
+\beta 7 E B T P+\beta 8 T N H+\beta 9 E B T P * T N H+\beta 10 T N L+\beta 11 E B T P * T N L \\
+e i, t \quad \text { Equation (4) }
\end{gathered}
$$

The results are reported in Column 3 and 4 of Table 3 and 4. The EBTP coefficient is positively significant, and suggests that loan loss provisions are used to smooth reported earnings while EBTP*TNH coefficient reports a negative sign and is significant in Column 3 of Table 3 and 4, implying that banks do not use loan loss provisions to smooth income when they have substantial investment in intangible assets. EBTP*TNL coefficient reports a 
positive sign and is significant in Column 4 of Table 3 and 4, indicating that banks use loan loss provisions to smooth income when they have low intangible assets. Interestingly, this suggest that African banks possibly use loan loss provisions to smooth bank earnings to appear profitable when they have low investment in intangible assets that yields low returns which do not significantly improve bank profitability or bank value.

\subsubsection{The influence of investor protection}

Next, we test whether the association between loan loss provision and bank intangibles is influenced by minority shareholder right protection differences across African countries. To do this, we interact TN with INVP and the result is reported in Column 5 of Table 3 and 4.

$$
\begin{aligned}
& L L P=\beta 1 L L P t-1+\beta 2 T N+\beta 3 L O A N+\beta 4 L O T A+\beta 5 C A P+\beta 6 \triangle G D P \\
& +\beta 7 I N V P+\beta 8 T N H+\beta 9 T N L+\beta 10 E B T P+\beta 11 T N * I N V P \\
& +\beta 12 E B T P * T N H * I N V P+\beta 13 E B T P * T N L * I N V P+\text { eit } \quad \text { Equation } 5
\end{aligned}
$$

TN*INVP coefficient reports a negative sign and is weakly significant in Table 3 , and is positive but insignificant Table 4, indicating that the association between loan loss provisions and bank intangibles is weakened when banks are in countries with strong minority shareholder right protection. Finally, we test whether the association between loan loss provisions, transient bank intangibles and income smoothing incentives is influenced by differences in the level of minority shareholder right protection. The result is reported in Column 6 and 7 of Table 3 and 4. INVP*EBTP*TNH coefficient is negatively significant, indicating that banks in African countries with strong minority shareholder right protection do not use provisions to smooth income when they have substantial intangible assets. 
INVP*EBTP*TNL coefficient is insignificant in Column 7 of Table 3 but is positive and weakly significant in Table 4, hence no meaningful conclusion can be drawn.

\section{Conclusion}

In this study, we investigate the relationship between loan loss provisions and bank intangibles. Prior studies show that discretionary loan loss provisions are used for several purposes rather than solely for credit risk management purposes. We extend the debate to understand whether discretionary loan loss provisions are also driven by the level of, and changes in, bank intangible assets in the balance sheet of banks. Our findings indicate that discretionary loan loss provision is inversely related with bank intangible assets and change in intangible assets. Also, African banks appear to use discretionary provisions to smooth income when they have low intangible assets but do not use discretionary provisions to smooth income when they have substantial or high intangible assets. Moreover, the association between discretionary loan loss provisions and bank intangibles is weakened among banks in African countries that have strong investor protection. Further, banks in African countries with strong minority shareholder right protection do not use discretionary provisions to smooth income when they have substantial intangibles.

The main implication of the findings is that strong investor protection in Africa can discourage African banks from using discretionary loan loss provisions to signal the riskiness of intangible asset investments.

Finally, the study did not use data on actual gains and losses realized from investment in intangible assets because (i) actual gains and losses from intangible asset investments are 
difficult to measure, (ii) such gains and losses from intangible asset investments extend beyond one or more years, and (iii) they are subject to overestimation or underestimation due to recognitions issues if reported in financial reports. Hence, future research can provide additional insights by employing data on gains and losses on intangible assets to examine the relationship between bank provisions and intangible asset valuation, when such data become available. 


\section{Reference}

Abdolmohammadi, M. J. (2005), 'Intellectual capital disclosure and market capitalization', Journal of Intellectual Capital, Vol. 6 No. 3, pp. 397-416.

Ahmed, A. S., Takeda, C., \& Thomas, S. (1999), 'Bank loan loss provisions: a reexamination of capital management, earnings management and signaling effects', Journal of Accounting and Economics, Vol. 28 No.1, pp. 1-25.

Akerlof, G. (1970), 'The Market for 'Lemons: Quality Uncertainty and the Market Mechanism', Quantitative Journal of Economics, Vol. 89, pp. 488-500.

Amor, A. B. (2017), 'Ownership structure and bank risk-taking: empirical evidence from Tunisian banks', Afro-Asian Journal of Finance and Accounting, Vol. 7 No.3, pp. 227-241.

Andonova, V., \& Ruíz-Pava, G. (2016), 'The role of industry factors and intangible assets in company performance in Colombia', Journal of Business Research, Vol. 69 No. 10, pp. 43774384.

Arellano, M. and Bond, S. (1991), 'Some Tests of Specification for Panel Data: Monte Carlo Evidence and an Application to Employment Equations', The Review of Economic Studies, Vol. 58 No. 2, pp. 277-297. 
Arrighetti, A., Landini, F., \& Lasagni, A. (2014), 'Intangible assets and firm heterogeneity:

Evidence from Italy', Research Policy, Vol. 43 No. 1, pp. 202-213.

Basu, S., and Waymire, G. (2008), 'Has the Importance of Intangibles Really Grown? And if so, why?', Accounting and Business Research, Vol. 38, No.3, pp. 171-190.

Beaver, W., and Engel, E. (1996), 'Discretionary Behaviour with Respect to Allowances for Loan Losses and the Behaviour of Stock Prices', Journal of Accounting and Economics, Vol. 22, pp. 177-206.

Beaver, W., Eger, C., Ryan, S., and Wolfson, M. (1989), 'Financial Reporting and the Structure of Bank Share Prices', Journal of Accounting Research, Vol. 27, pp. 157-178.

Bikker, J. A., and Metzemakers, P. A. (2005), 'Bank Provisioning Behaviour and Procyclicality', Journal of International Financial Markets, Institutions and Money, Vol. 15 No. 2, pp. 141-157.

Bonin, J., and Kosak, M. (2013), 'Loan Loss Provisioning in Emerging Europe: Precautionary or Pro-Cyclical?' Working Paper 10, Wesleyan University, Department of Economics.

Brown, S., Lo, K., and Lys, T. (1999), 'Use of R2 in accounting research: Measuring changes in value relevance over the last four decades', Journal of Accounting and Economics, Vol. 28, pp. 83-115. 
Bushman, R. M., \& Williams, C. D. (2012), 'Accounting discretion, loan loss provisioning, and discipline of banks' risk-taking', Journal of Accounting and Economics, Vol. 54, pp. 1-18.

Chen, L., Danbolt, J., and Holland, J. (2014), 'Rethinking bank business models: the role of intangibles', Accounting, Auditing \& Accountability Journal, Vol. 27 No. 3, pp. 563-589.

Cohen, L. J., Cornett, M. M., Marcus, A. J., \& Tehranian, H. (2014), ‘Bank earnings management and tail risk during the financial crisis', Journal of Money, Credit and Banking, Vol. 46 No. 1, pp. 171-197.

Curcio, D., and Hasan, I. (2015), 'Earnings and Capital Management and Signaling: the use of Loan Loss Provisions by European Banks', The European Journal of Finance, Vol. 21 No. 1, pp. 26-50.

Donaldson, T. H. (2016), 'The treatment of intangibles: A banker's view', Springer.

Eberhart, A., Maxwell, W., and Siddique, A. (2004), 'An examination of long-term abnormal stock returns and operating performance following R\&D increases', Journal of Finance, Vol. 59 No. 2, pp. 623-650.

Financial Accounting Standards Board. (2001), 'Getting a grip on intangible assets-what they are, why they matter, and who should be managing them in your organization', Harvard Management Update, Vol. 6 No. 2, pp. 6-8 
Fonseca, A. R., and Gonzalez, F. (2008), ‘Cross-country Determinants of Bank Income Smoothing by Managing Loan Loss Provisions' Journal of Banking and Finance, Vol. 32 No. 2, pp. 217-228.

Garcia-Ayuso, M. (2003), 'Factors explaining the inefficient valuation of intangibles. Accounting, Auditing, Accountability Journal, Vol. 16 No. 1, pp. 67-69.

International Accounting Standards Board - IASB. (2004), 'Intangible assets', International Accounting Standards No. 38. London, UK (revised).

Jones, D. (2007), 'Voluntary disclosure in R\&D-intensive industries', Contemporary Accounting Research, Vol. 24 No. 2, pp. 489-522.

Kanagaretnam, K., Lobo, G., and Yang, D. (2004), ‘Joint Tests of Signalling and Income Smoothing through Bank Loan Loss Provisions', Contemporary Accounting Research, Vol. 21, pp. 843-884.

Kanagaretnam, K., Lobo, G. and Yang, D. (2005), 'Determinants of Signalling by Banks through Loan Loss Provisions, Journal of Business Research, Vol. 58, pp. 312-320.

Kristandl, G., and Bontis, N. (2007), 'The impact of voluntary disclosure on cost of equity capital estimates in a temporal setting, Journal of Intellectual Capital, Vol. 8 No. 4, pp. 577594. 
Laeven, L., and Majnoni, G. (2003), 'Loan Loss Provisioning and Economic Slowdowns: Too Much, Too Late?' Journal of Financial Intermediation, Vol. 12 No. 2, pp. 178-197.

Lev, B. (2001), Intangibles: Management, measurement and reporting' Washington, DC: Brookings Institution Press.

Lev, B., and Zarowin, P. (1999), 'The boundaries of financial reporting and how to extend them', Journal of Accounting Research, Vol. 37 No. 2, pp. 353-385.

Leventis, S., Dimitropoulos, P. E., and Anandarajan, A. (2012), 'Signalling by Banks Using Loan Loss Provisions: The Case of the European Union', Journal of Economic Studies, Vol. 39 No. 5, pp. 604-618.

Liu, C., and Ryan, S. (1995), 'The Effect of Bank Loan Portfolio Composition on the Market Reaction to and Anticipation of Loan Loss Provisions', Journal of Accounting Research, Vol. 33, pp. 77-94.

Liu, C., Ryan, S., and Wahlen, J. (1997), 'Differential Valuation Implications of Loan Loss Provisions across Bank and Fiscal agents,' The Accounting Review, Vol. 72, pp. 133-146.

Morris, R. D., Kang, H., \& Jie, J. (2016), 'The determinants and value relevance of banks' discretionary loan loss provisions during the financial crisis,' Journal of Contemporary Accounting \& Economics, Vol. 12 No. 2, pp. 176-190. 
Nicolo, A., and Pelizzon, L. (2008), 'Credit derivatives, Capital Requirements and Opaque OTC Markets, Journal of Financial Intermediation, Vol. 17, pp. 444-463.

Oliveira, L., Rodrigues, L. L., \& Craig, R. (2010), 'Intangible assets and value relevance: Evidence from the Portuguese stock exchange,' The British Accounting Review, Vol. 42 No.4, pp. 241-252.

Orens, R., Aerts, W., and Lybaert, N. (2009), 'Intellectual capital disclosure cost of finance and firm value. Management Decision, Vol. 47 No. 10, pp. 1536-1554.

Ozili, P. K. (2015), 'Loan Loss Provisioning, Income Smoothing, Signaling, Capital Management and Procyclicality: Does IFRS Matter? Empirical Evidence from Nigeria', Mediterranean Journal of Social Sciences, Vol. 6 No. 2, pp. 224-232.

Ozili, P. K., \& Outa, E. (2017). Bank Loan Loss Provisions Research: A Review. Borsa Istanbul Review. Vol. 17, No. 3, pp. 144-163.

Ozili, P. K. (2018). Bank loan loss provisions, investor protection and the macroeconomy. International Journal of Emerging Markets, Vol. 13, No.1.

Reily R. F. (2010), 'Intangible Asset Identification and Valuation in the Bank and Thrift Industries'. Available at: http://www.willamette.com/insights journal/10/winter 2010 10.pdf Accessed 20/06/2016. 
Riro, G. K., Waweru, N. M., \& Uliana, E. O. (2016). Quality of corporate reporting: case studies from an emerging capital market. Afro-Asian Journal of Finance and Accounting, Vol. 6 No.1, pp. 31-52.

Scholes, M., Wilson, G.P., and Wolfson, M. (1990), 'Tax Planning, Regulatory Capital Planning and Financial Reporting Strategy for Commercial Banks', Review of Financial Studies, Vol. 3, pp. 625-650.

Seow, G., Shangguan, Z., and Vasudevan, G. (2006), 'Intangible investments and the cost of equity capital', The International Journal of Finance, Vol. 18 No. 2, pp. 3980-4012.

Shen, C. H., and Chih, H. L. (2005), 'Investor Protection, Prospect Theory, and Earnings Management: An International Comparison of the Banking Industry, Journal of Banking and Finance, Vol. 29 No. 10, pp. 2675-2697.

Vergauwen, P., Bollen, L., and Oirbans, E. (2007), 'Intellectual capital disclosure and intangible value drivers: An empirical study. Management Decision, Vol. 45 No. 7, pp. 11631180.

Visvanathan, G. (2017), 'Intangible assets on the balance sheet and audit fees', International Journal of Disclosure and Governance, Vol. 14 No. 3, pp. 241-250. 
Wahlen, J. (1994), 'The Nature of Information in Commercial Bank Loan Loss Disclosures', The Accounting Review, Vol. 69, pp. 455-478.

Zéghal, D., and Maaloul, A. (2011). The accounting treatment of intangibles. A critical review of the literature. Accounting Forum, Vol. 35 No. 4, pp. 262-274. 
Tables

\begin{tabular}{|c|c|c|c|c|c|c|c|c|c|}
\hline \multicolumn{10}{|c|}{ Table 1. Descriptive Statistics: Summary } \\
\hline & LLP & TN & $\Delta$ TN & CAP & INVP & LOAN & LOTA & EBTP & $\Delta$ GDP \\
\hline Mean & 0.011 & 0.008 & 0.126 & 16.109 & 4.614 & 0.206 & 50.968 & 0.032 & 0.056 \\
\hline Median & 0.006 & 0.003 & 0.104 & 11.945 & 5.300 & 0.167 & 51.345 & 0.029 & 0.052 \\
\hline Maximum & 0.269 & 0.219 & -4.03 & 99.860 & 8.000 & 0.992 & 121.9 & 0.335 & 0.337 \\
\hline Minimum & -0.286 & 0.000 & -1.000 & -24.000 & -1.070 & -0.816 & 0.000 & -0.296 & -0.076 \\
\hline & & & & & & & & & \\
\hline Observations & 2622 & 2125 & 1809 & 2744 & 2316 & 2353 & 2722 & 2610 & 3666 \\
\hline
\end{tabular}


Table 2: Correlation Matrix

\begin{tabular}{|c|c|c|c|c|c|c|c|c|c|c|}
\hline Correlation & LLP & TN & $\Delta T N$ & EBTP & LOTA & LOAN & $\Delta \mathrm{GDP}$ & TNH & TNL & INVP \\
\hline \multirow[t]{2}{*}{ LLP } & 1.000 & & & & & & & & & \\
\hline & ----- & & & & & & & & & \\
\hline \multirow[t]{2}{*}{ TN } & $0.219^{* * *}$ & 1.000 & & & & & & & & \\
\hline & 0.000 & ---- & & & & & & & & \\
\hline \multirow[t]{2}{*}{$\Delta \mathrm{TN}$} & 0.038 & 0.0453 & 1.000 & & & & & & & \\
\hline & 0.195 & 0.122 & ---- & & & & & & & \\
\hline \multirow[t]{2}{*}{ EBTP } & $0.403 * * *$ & $0.110 * * *$ & -0.001 & 1.000 & & & & & & \\
\hline & 0.000 & 0.000 & 0.963 & ----- & & & & & & \\
\hline \multirow[t]{2}{*}{ LOTA } & 0.001 & -0.015 & -0.001 & $0.063^{* *}$ & 1.000 & & & & & \\
\hline & 0.986 & 0.618 & 0.986 & 0.030 & ----- & & & & & \\
\hline \multirow[t]{2}{*}{ LOAN } & 0.043 & -0.008 & 0.044 & $0.094 * * *$ & -0.045 & 1.000 & & & & \\
\hline & 0.137 & 0.759 & 0.129 & 0.001 & 0.116 & ----- & & & & \\
\hline \multirow[t]{2}{*}{$\Delta \mathrm{GDP}$} & -0.018 & $-0.078 * * *$ & 0.031 & -0.014 & $-0.236 * * *$ & $0.280 * * *$ & $\quad 1.000$ & & & \\
\hline & 0.522 & 0.007 & 0.295 & 0.626 & 0.000 & 0.000 & ----- & & & \\
\hline \multirow[t]{2}{*}{ TNH } & $0.132 * * *$ & $0.614^{* * *}$ & 0.031 & 0.017 & -0.004 & $-0.057^{*}$ & $-0.087^{* * *}$ & 1.000 & & \\
\hline & 0.000 & 0.000 & 0.290 & 0.548 & 0.899 & 0.051 & 0.003 & ----- & & \\
\hline \multirow[t]{2}{*}{ TNL } & $-0.108^{* * *}$ & $-0.505^{* * *}$ & -0.032 & 0.005 & $-0.053^{*}$ & 0.014 & $0.082^{* * *}$ & $-0.667^{* * *}$ & 1.000 & \\
\hline & 0.000 & 0.000 & 0.275 & 0.866 & 0.069 & 0.622 & 0.005 & 0.000 & ----- & \\
\hline \multirow[t]{2}{*}{ INVP } & $0.066^{* *}$ & 0.044 & $-0.049 *$ & 0.016 & 0.027 & -0.033 & $-0.077 * * *$ & 0.022 & -0.019 & 1.000 \\
\hline & 0.024 & 0.132 & 0.089 & 0.571 & 0.352 & 0.262 & 0.009 & 0.454 & 0.502 & ----- \\
\hline
\end{tabular}




\begin{tabular}{|c|c|c|c|c|c|c|c|}
\hline \multicolumn{8}{|c|}{ Table 3: Main Regression - Fixed Effect OLS } \\
\hline & (1) & (2) & (3) & (4) & (5) & (6) & (7) \\
\hline C & $\begin{array}{c}0.009^{* * *} \\
(3.28) \\
\end{array}$ & $\begin{array}{l}0.006^{*} \\
(1.89) \\
\end{array}$ & $\begin{array}{l}0.004 \\
(1.45) \\
\end{array}$ & $\begin{array}{c}0.014^{* * *} \\
(4.83) \\
\end{array}$ & $\begin{array}{l}0.005 \\
(0.93) \\
\end{array}$ & $\begin{array}{l}0.003 \\
(0.63) \\
\end{array}$ & $\begin{array}{l}0.005 \\
(0.97) \\
\end{array}$ \\
\hline TN & $\begin{array}{c}-0.175^{* * *} \\
(-3.84)\end{array}$ & & $\begin{array}{c}-0.157^{* * *} \\
(-3.21)\end{array}$ & $\begin{array}{c}-0.181^{* * *} \\
(-3.96)\end{array}$ & $\begin{array}{l}0.027 \\
(0.27) \\
\end{array}$ & $\begin{array}{c}-0.138^{* * *} \\
(-2.79)\end{array}$ & $\begin{array}{c}-0.135^{* * *} \\
(-2.93)\end{array}$ \\
\hline$\Delta T N$ & & $\begin{array}{l}0.0001 \\
(0.35)\end{array}$ & & & & & \\
\hline LOAN & $\begin{array}{c}-0.006 * * * \\
(-3.10) \\
\end{array}$ & $\begin{array}{l}-0.003^{*} \\
(-1.68) \\
\end{array}$ & $\begin{array}{c}-0.007^{* * *} \\
(-4.21)\end{array}$ & $\begin{array}{c}-0.007 * * * \\
(-4.19) \\
\end{array}$ & $\begin{array}{c}-0.007 * * * \\
(-3.98) \\
\end{array}$ & $\begin{array}{c}-0.008^{* * *} \\
(-4.75) \\
\end{array}$ & $\begin{array}{c}-0.008^{* * *} \\
(-4.69) \\
\end{array}$ \\
\hline LOTA & $\begin{array}{c}0.0001^{* * *} \\
(2.80)\end{array}$ & $\begin{array}{c}0.0002^{* * *} \\
(2.77)\end{array}$ & $\begin{array}{c}0.0001^{* *} \\
(2.17)\end{array}$ & $\begin{array}{c}0.0001^{*} \\
(1.93)\end{array}$ & $\begin{array}{c}0.0002^{* * *} \\
(3.44)\end{array}$ & $\begin{array}{c}0.0001^{* * *} \\
(2.89)\end{array}$ & $\begin{array}{c}0.0001 * * * \\
(3.01)\end{array}$ \\
\hline CAP & $\begin{array}{c}- \\
0.0003^{* * *} \\
(-4.25)\end{array}$ & $\begin{array}{c}-0.0003^{* * *} \\
(-3.24)\end{array}$ & $\begin{array}{c}-0.0005^{* * *} \\
(-7.03)\end{array}$ & $\begin{array}{c}- \\
0.0005^{* * *} \\
(-6.51)\end{array}$ & $\begin{array}{l}-0.0001 \\
(-1.07)\end{array}$ & $\begin{array}{c}-0.0003^{* * *} \\
(-3.43)\end{array}$ & $\begin{array}{c}-0.0003^{* * * *} \\
(-3.77)\end{array}$ \\
\hline$\triangle \mathrm{GDP}$ & $\begin{array}{l}0.009 \\
(0.67)\end{array}$ & $\begin{array}{l}0.001 \\
(0.07)\end{array}$ & $\begin{array}{l}0.019 \\
(1.37)\end{array}$ & $\begin{array}{l}0.018 \\
(1.26)\end{array}$ & $\begin{array}{l}0.008 \\
(0.69)\end{array}$ & $\begin{array}{l}0.011 \\
(0.93)\end{array}$ & $\begin{array}{l}0.013 \\
(1.07)\end{array}$ \\
\hline $\mathrm{TNH}$ & & & $\begin{array}{c}0.009 * * * \\
(5.34)\end{array}$ & & & $\begin{array}{c}0.004^{* * *} \\
(2.70) \\
\end{array}$ & \\
\hline TNL & & & & $\begin{array}{c}-0.013 * * * \\
(-9.04) \\
\end{array}$ & & & $\begin{array}{l}-0.002 \\
(-1.49) \\
\end{array}$ \\
\hline EBTP & & & $\begin{array}{c}0.306^{* * *} \\
(13.49)\end{array}$ & $\begin{array}{c}0.081^{* * *} \\
(3.25)\end{array}$ & & $\begin{array}{c}0.201^{* * *} \\
(9.59)\end{array}$ & $\begin{array}{c}0.184^{* * *} \\
(8.60)\end{array}$ \\
\hline EBTP*TNH & & & $\begin{array}{c}-0.223 * * * \\
(-6.87)\end{array}$ & & & & \\
\hline EBTP*TNL & & & & $\begin{array}{c}0.293^{* * *} \\
(10.17)\end{array}$ & & & \\
\hline INVP & & & & & $\begin{array}{l}-0.0002 \\
(-0.22)\end{array}$ & $\begin{array}{l}-0.0004 \\
(-0.37)\end{array}$ & $\begin{array}{c}-0.0003 \\
(-0.31)\end{array}$ \\
\hline INVP*TN & & & & & $\begin{array}{l}-0.030^{*} \\
(-1.92)\end{array}$ & & \\
\hline INVP*EBTP*TNH & & & & & & $\begin{array}{c}-0.012^{* * *} \\
(-2.86)\end{array}$ & \\
\hline INVTP*EBTP*TNL & & & & & & & $\begin{array}{l}-0.001 \\
(-0.18)\end{array}$ \\
\hline Fixed Effects? & Yes & Yes & Yes & Yes & Yes & Yes & Yes \\
\hline F-Statistic & 7.02 & 5.45 & 8.39 & 8.96 & 9.11 & 10.14 & 10.03 \\
\hline p-value (F-Statistic) & 0.000 & 0.000 & 0.000 & 0.000 & 0.000 & 0.000 & 0.000 \\
\hline Durbin Watson & 1.85 & 1.99 & 1.89 & 1.91 & 1.97 & 1.99 & 2.01 \\
\hline Observations & 1783 & 1493 & 1772 & 1771 & 1217 & 1211 & 1210 \\
\hline $\begin{array}{l}\text { T-Statistics are report } \\
\text { regression include co } \\
\text { asset ratio. EBTP = Ea } \\
\text { total asset ratio. LOA } \\
\text { protection, higher val } \\
\text { ratio (TN) ratio is abo } \\
\text { equals one if intangib } \\
\text { banks have low intan }\end{array}$ & $\begin{array}{l}\text {, bank and } \\
\text { s before pr } \\
\text { an growth } \\
\text { ndicate str } \\
6 \text { and zero } \\
\text { set to total } \\
\text { 5. }\end{array}$ & $\begin{array}{l}* * *, * *, * \text { ir } \\
\text { ar fixed effe } \\
t \text { and tax to } \\
\text { e. } \triangle \mathrm{GDP}=\mathrm{r} \\
\text { investor pr } \\
\text { erwise, repr } \\
\text { set ratio (TN }\end{array}$ & $\begin{array}{l}\text { Cate signific } \\
\text {. OLS stand } \\
\text { tal asset rat } \\
\text { gross dome } \\
\text { ection. TNH } \\
\text { enting peric } \\
\text { atio is less t }\end{array}$ & $\begin{array}{l}\text { e at the } 0 \\
\text { error is no } \\
\text { CAP }=\text { tota } \\
\text { product } \\
\text { ummy var } \\
\text { when ban } \\
0.5 \% \text { and }\end{array}$ & $\begin{array}{l}\text { 0.05, and } 0 \\
\text { lustered. } \Delta \mathrm{T} \\
\text { quity to total } \\
\text { wth rate. IN } \\
\text { le equals on } \\
\text { have high int } \\
\text { ro otherwise }\end{array}$ & $\begin{array}{l}\text { level, resp } \\
\text { : change in i } \\
\text { set ratio. LC } \\
=\text { minority } \\
\text { intangible } \\
\text { gibles. TNL } \\
\text { epresenting }\end{array}$ & $\begin{array}{l}\text { y. OLS } \\
\text { ible to total } \\
\text { total loan to } \\
\text { holder right } \\
\text { to total asset } \\
\text { my variable } \\
\text { ds when }\end{array}$ \\
\hline
\end{tabular}




\begin{tabular}{|c|c|c|c|c|c|c|c|}
\hline & (1) & (2) & (3) & (4) & (5) & (6) & (7) \\
\hline LLPt-1 & $\begin{array}{c}-0.048^{* * *} \\
(-13.49)\end{array}$ & $\begin{array}{c}-0.010^{* * *} \\
(-4.08)\end{array}$ & $\begin{array}{c}-0.103 * * * \\
(-21.33)\end{array}$ & $\begin{array}{c}-0.152^{* * *} \\
(-16.21)\end{array}$ & $\begin{array}{c}0.274^{* * *} \\
(4.86)\end{array}$ & $\begin{array}{l}0.111^{*} \\
(1.95)\end{array}$ & $\begin{array}{c}0.160 * * * \\
(2.68)\end{array}$ \\
\hline TN & $\begin{array}{c}-0.228^{* *} \\
(-1.98)\end{array}$ & & $\begin{array}{c}-0.727^{* * *} \\
(-4.05)\end{array}$ & $\begin{array}{c}-0.659 * * * \\
(-5.07)\end{array}$ & $\begin{array}{l}-1.086 \\
(-1.32)\end{array}$ & $\begin{array}{c}-0.699 * * \\
(-2.34)\end{array}$ & $\begin{array}{c}-0.421^{*} \\
(-1.65)\end{array}$ \\
\hline$\Delta \mathrm{TN}$ & & $\begin{array}{c}-0.001^{* * *} \\
(-2.83)\end{array}$ & & & & & \\
\hline LOAN & $\begin{array}{c}-0.010^{* * *} \\
(-5.41)\end{array}$ & $\begin{array}{c}-0.017 * * * \\
(-10.33)\end{array}$ & $\begin{array}{c}-0.009 * * \\
(-2.52)\end{array}$ & $\begin{array}{c}-0.018^{* * *} \\
(-4.72)\end{array}$ & $\begin{array}{c}-0.016 * * * \\
(-3.63)\end{array}$ & $\begin{array}{c}-0.016 * * \\
(-1.98)\end{array}$ & $\begin{array}{c}-0.019 * * \\
(-2.29)\end{array}$ \\
\hline LOTA & $\begin{array}{c}0.001 * * * \\
(15.46)\end{array}$ & $\begin{array}{c}0.001^{* * *} \\
(13.72)\end{array}$ & $\begin{array}{l}0.0002 \\
(1.47) \\
\end{array}$ & $\begin{array}{c}0.0005^{* * *} \\
(3.58)\end{array}$ & $\begin{array}{c}0.0004^{* * *} \\
(2.48)\end{array}$ & $\begin{array}{l}0.0001 \\
(-0.36) \\
\end{array}$ & $\begin{array}{l}0.0003 \\
(1.32) \\
\end{array}$ \\
\hline CAP & $\begin{array}{c}-0.003 * * * \\
(-25.29)\end{array}$ & $\begin{array}{c}-0.003^{* * *} \\
(-10.60)\end{array}$ & $\begin{array}{c}-0.002^{* * *} \\
(-15.09)\end{array}$ & $\begin{array}{c}-0.002^{* * *} \\
(-7.46)\end{array}$ & $\begin{array}{c}0.0004 \\
(1.09)\end{array}$ & $\begin{array}{c}-0.00002 \\
(-0.05)\end{array}$ & $\begin{array}{c}0.00004 \\
(0.11)\end{array}$ \\
\hline$\triangle G D P$ & $\begin{array}{c}-0116 * * * \\
(-16.26)\end{array}$ & $\begin{array}{c}-0.071^{* * *} \\
(-6.10)\end{array}$ & $\begin{array}{l}-0.002 \\
(-0.07)\end{array}$ & $\begin{array}{c}0.065^{* * *} \\
(3.02)\end{array}$ & $\begin{array}{l}-0.035 \\
(-0.56)\end{array}$ & $\begin{array}{l}-0.036 \\
(-0.39)\end{array}$ & $\begin{array}{c}-0.176^{* *} \\
(-2.52)\end{array}$ \\
\hline TNH & & & $\begin{array}{c}0.022^{* * *} \\
(3.20)\end{array}$ & & & $\begin{array}{l}0.027^{*} \\
(1.79)\end{array}$ & \\
\hline TNL & & & & $\begin{array}{c}-0.014^{* * *} \\
(-3.89)\end{array}$ & & & $\begin{array}{c}0.021^{* * *} \\
(3.68)\end{array}$ \\
\hline EBTP & & & $\begin{array}{c}0.688^{* * *} \\
(17.63) \\
\end{array}$ & $\begin{array}{c}0.134^{* * *} \\
(9.40)\end{array}$ & & $\begin{array}{c}0.484^{* * *} \\
(6.05)\end{array}$ & $\begin{array}{c}0.308^{* *} \\
(2.41)\end{array}$ \\
\hline EBTP*TNH & & & $\begin{array}{c}-0.485^{* * *} \\
(-12.14)\end{array}$ & & & & \\
\hline EBTP*TNL & & & & $\begin{array}{c}0.818^{* * *} \\
(15.04)\end{array}$ & & & \\
\hline INVP & & & & & $\begin{array}{l}0.009 \\
(1.29)\end{array}$ & $\begin{array}{l}-0.007 \\
(-1.53)\end{array}$ & $\begin{array}{c}-0.021 * * * \\
(-3.15)\end{array}$ \\
\hline INVP*TN & & & & & $\begin{array}{l}0.097 \\
(0.93)\end{array}$ & & \\
\hline INVP*EBTP*TNH & & & & & & $\begin{array}{c}-0.041^{* *} \\
(-2.37)\end{array}$ & \\
\hline INVP*EBTP*TNL & & & & & & & $\begin{array}{l}0.026^{*} \\
(1.65)\end{array}$ \\
\hline Sarjan (J-statistic) & 52.03 & 48.06 & 45.74 & 51.70 & 23.27 & 23.94 & 11.37 \\
\hline P-value (J Statistic) & 0.394 & 0.429 & 0.483 & 0.261 & 0.592 & 0.465 & 0.986 \\
\hline $\mathrm{AR}(1)$ & 0.238 & 0.145 & 0.062 & 0.029 & & 0.001 & 0.0004 \\
\hline $\operatorname{AR}(2)$ & 0.405 & 0.170 & 0.229 & 0.067 & 0.091 & 0.071 & 0.079 \\
\hline Observations & 1235 & 1194 & 1226 & 1225 & 929 & 924 & 923 \\
\hline \multicolumn{8}{|c|}{$\begin{array}{l}\text { T-Statistics are reported in parentheses. }{ }^{* * *}, * *, * \text { indicate significance at the } 0.01,0.05, \text { and } 0.10 \text { level, respectively. } \\
\text { GMM regression is based on Arellano and Bond (1991) first-difference GMM estimator and includes first-difference and } \\
\text { period fixed effects. The GMM panel estimator controls for potential endogeneity by using instruments based on lagged } \\
\text { values of the explanatory variables in the model. GMM standard error is not clustered. EBTP = Earnings before profit and tax } \\
\text { to total asset ratio. CAP = total equity to total asset ratio. LOTA = total loan to total asset ratio. LOAN = loan growth rate. } \\
\Delta \mathrm{GDP}=\text { real gross domestic product growth rate. INVP = minority shareholder right protection and higher values indicate } \\
\text { strong investor protection. TNH = dummy variable equals one if intangible asset to total asset ratio (TN) ratio is above } 1 \% \\
\text { and zero otherwise, representing periods when banks have high intangibles. TNL = dummy variable equals one if intangible } \\
\text { asset to total asset ratio (TN) ratio is less than } 0.5 \% \text { and zero otherwise, representing periods when banks have low } \\
\text { intangibles. }\end{array}$} \\
\hline
\end{tabular}


Appendix

\begin{tabular}{|c|c|c|}
\hline \multicolumn{3}{|c|}{ Definition and Source of Main Variables } \\
\hline Variable & Description & Source \\
\hline LLP & Ratio of loan loss provisions to total assets. & Bankscope database \\
\hline TN & Ratio of intangibles to total assets. & Bankscope database \\
\hline$\Delta \mathrm{TN}$ & Change in intangibles to total assets ratio. & Bankscope database \\
\hline CAP & Ratio of total equity to total assets. & Bankscope database \\
\hline EBTP & Ratio of earnings before provisions and taxes to total assets. & Bankscope database \\
\hline LOAN & Loan growth is change in gross loan outstanding. & Bankscope database \\
\hline LOTA & Ratio of total loans to total assets. & Bankscope database \\
\hline$\Delta \mathrm{GDP}$ & Growth in real gross domestic product & World Economic Forum \\
\hline INVP & $\begin{array}{l}\text { Refer to 'strength of investor protection index'. It measures } \\
\text { the strength of minority shareholder protection against the } \\
\text { misuse of corporate assets by directors for personal gain. The } \\
\text { index ranges from } 0 \text { to } 10 \text { with higher values indicating } \\
\text { stronger minority shareholders protection. }\end{array}$ & $\begin{array}{l}\text { Doing Business Project, } \\
\text { archived in World Bank } \\
\text { database. }\end{array}$ \\
\hline
\end{tabular}

